\title{
The importance of a training program on active aging from the perspective of elderly individuals
}

\author{
Importância de um programa formativo sobre envelhecimento ativo na perspectiva das pessoas idosas
}

Importancia de un programa de formación sobre envejecimiento activo desde la perspectiva de las personas ancianas

\section{Maria Gorete Mendonça Reis',11 ORCID: 0000-0003-1001-4142 \\ Maria Vitória Casas-Novas' ORCID: 0000-0002-5559-2715 \\ Isaura Serra' \\ ORCID: 0000-0002-1225-6631 \\ Maria Dulce Domingues Cabral Magalhães ORCID: 0000-0001-8825-4942 \\ Luís Manuel Mota Sousa',"11 ORCID: 0000-0002-9708-5690}

'Universidade de Évora, Departamento de Enfermagem. Évora, Portugal.

"Comprehensive Health Research Centre. Lisboa, Portugal.

How to cite this article: Reis MGM, Casas-Novas MV, Serra I, Magalhães MDDC Sousa LMM. The importance of a training program on active aging from the perspective of elderly individuals. Rev Bras Enferm. 2021;74(Suppl 2):e20190843 doi: http://dx.doi.org/10.1590/0034-7167-2019-0843

Corresponding author: Maria Gorete Mendonça Reis E-mail: greis@uevora.pt

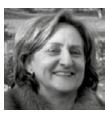

EDITOR IN CHIEF: Antonio José De Almeida Filho ASSOCIATE EDITOR: Ana Fátima Fernandes

Submission: 11-28-2019 Approval: 04-30-2020

\section{ABSTRACT}

Objective: to assess the results of a training program focused on the well-being of elderly individuals from the perspective of users, through the opinion on the program impact on their active aging. Methods: a qualitative research, carried out from an intentional sample, consisting of 10 elderly women. Interview conducted by focus group, recorded and transcribed, which constituted the corpus of analysis. Lexical analysis of textual data was performed using the Alceste software. Results: from the analysis, three classes emerged: 1) Health-Activity; 2) Activity-Expectation; 3) Mind-Body Unit. The Activity-Expectation class stands out. Conclusions: the research revealed that elderly individuals consider it important to have expectation, which results in satisfaction and involvement with life as well as the ability to remain active in a perspective of mind-body unit. Future projects should focus on enhancing mental and physical functions to promote active and healthy aging.

Descriptors: Aging; Program Evaluation; Health Education; Delivery of Health Care; Aged.

\section{RESUMO}

Objetivo: avaliar os resultados de um programa formativo focado no bem-estar do idoso na perspectiva dos utilizadores, por meio da opinião sobre o impacto do programa no seu envelhecimento ativo. Métodos: pesquisa qualitativa, realizada a partir de uma amostra intencional, constituída por 10 mulheres idosas. Entrevista realizada por focus group, gravada e transcrita, a qual constituiu o corpus da análise. A análise lexical dos dados textuais foi realizada por meio do software Alceste. Resultados: da análise, emergiram três classes: 1 ) Saúde-Atividade; 2) Atividade-Expectativa; 3) Unidade Mente-Corpo. Destaca-se a classe Atividade-Expectativa. Conclusões: a pesquisa revelou que os idosos consideram ser importante ter expectativa, que se concretiza na satisfação e envolvimento com a vida, bem como a capacidade de se manterem ativos em uma perspectiva da unidade mentecorpo. Os projetos futuros devem focar na estimulação das funções mentais e físicas, para promoverem envelhecimento ativo e saudável.

Descritores: Envelhecimento; Avaliação de Programas e Projetos de Saúde; Educação em Saúde; Assistência à Saúde; Idoso.

\section{RESUMEN}

Objetivo: evaluar los resultados de un programa de capacitación centrado en el bienestar de las personas mayores desde la perspectiva de los usuarios, a través de la opinión sobre el impacto del programa en su envejecimiento activo. Métodos: investigación cualitativa, realizada a partir de una muestra intencional, compuesta por 10 mujeres mayores. Entrevista realizada por grupo focal, grabada y transcrita, que constituyó el corpus del análisis. El análisis léxico de datos textuales se realizó con el software Alceste. Resultados: surgieron tres clases del análisis: 1) Actividad de salud; 2) Actividad-Expectativa; 3) Unidad Mente-Cuerpo. Se destaca la clase Actividad-Expectativa. Conclusiones: la investigación reveló que los ancianos consideran importante tener expectativas, que se expresan en la satisfacción y la participación en la vida, así como la capacidad de permanecer activos en una perspectiva de la unidad mente-cuerpo. Los proyectos futuros deberían centrarse en estimular las funciones mentales y físicas, para promover el envejecimiento activo y saludable.

Descriptores: Envejecimento; Evaluación de Programas y Proyectos de Salud; Educación en Salud; Prestación de Atención de Salud; Anciano. 


\section{INTRODUCTION}

Demographic changes challenge societies and countries to create programs, policies and practices that promote active aging, taking into account the growth and/or maintenance of people's skills ${ }^{(1)}$. Such changes imply profound changes in personal and family relationships, and by the social, economic and cultural impact. In this regard, analysis of active aging and social dynamics today deals with demographic aging as a challenge to the reflection of European countries about their models of collective organization and the position of elderly people in contemporary societies ${ }^{(2)}$. It is imperative to reconcile collective and individual responsibilities towards this objective, exposing aging in a positive way. Thus, adopting a lifestyle that promotes well-being and full citizenship is a path that requires change in the perspective of how aging is seen today. Recently and in line with the evidenced perspective, the concept of aging in place has been presented, which refers to the meaning of living at home and in the community, in a safe and independent way, as one ages ${ }^{(3)}$.

The aging process reflects a continuum of life that must be supported by society through public policies, programs and resources aimed at citizens. These measures must take into account that the daily challenges are better managed when thought from the resources provided and the people's adaptability. Thus, it is evident the need to prepare for a change in attitude, in view of a life span that is prolonged and which aims to be lived with quality ${ }^{(1,4)}$. Such concern needs to be directed, mainly, to generations that did not have opportunities for schooling or with less education and/or were faced with high social and work difficulties.

The resources made available to care for elderly individuals are characterized differently, being offered in the form of a program or individual activities. Programs that offer a comprehensive and integrated approach are more recommended, as they combine several dimensions of human development. In this sense, the educational process must be transversal to the entire intervention and appropriate to the target audience. It is important to take care of the body, but also of the mind and human relationships, supporting people in developing appropriate strategies.

Successful aging ${ }^{(5)}$, in contrast to the negative perspective of aging, provides as principles to minimize the risk of disease and disability, maintain physical and mental function, and stay involved with life. There is still the possibility of disease, but there is an emphasis on functionality and citizen responsibility. Changes in the way society how perceives aging have broadened the view and studies on this phase of human life, bringing contributions to different areas, not just health, exclusively. Active aging is centered on the participation of the elderly population in health and self-care dimensions ${ }^{(6)}$, which benefits adhesion and permanence in programs destined to this public and in the training of the different agents with whom they relate. Aging in place reinforces this capacity by the possibility for elderly individuals to live in their home and in the community equally safely and independently.

Studying aging facilitates the learning process and the production of new knowledge about the physical, psychological and social changes associated with this stage of life. It implies giving space to life experience, recognizing freedom in decision making and supporting it, in order to put in place motivation strategies that support learning and change $\mathrm{e}^{(7)}$. Therefore, one realizes the importance of multidisciplinary and multifocal programs that are developed systematically, to reveal the effects, predict and assist in the difficulties experienced by elderly individuals.

The determinants of active aging ${ }^{(1-8)}$ are guidelines for interventions focused on health, physical, emotional and cognitive performance, autonomy, social relationships and commitment to life (Figure 1).

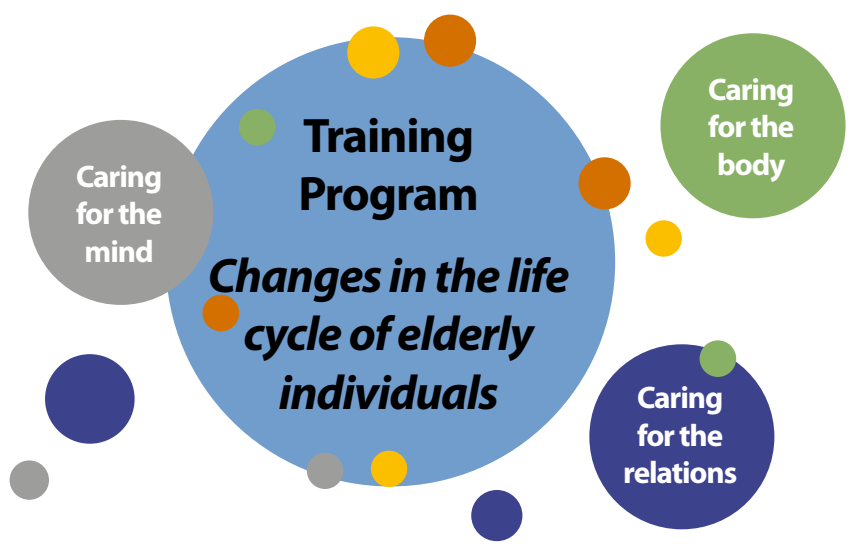

Figure 1 - Training program's focuses

The Vital Aging Program, for instance, is a program created in 2012, which followed the premises: $1^{\text {st }}$ ) There are different ways of aging and there is no single way to age well, based on empirical knowledge; $2^{\text {nd }}$ ) Diversity is not random, because external conditions are decisive and the action of each person personalizes the aging process; $3^{\text {rd }}$ ) The central nervous system maintains the plastic capacity throughout the life cycle, a characteristic that is expressed in learning and in the capacity for change; $4^{\text {th }}$ ) Selection, optimization, and compensation are adaptive mechanisms that allow changes to be made. It is considered that knowledge-based practice, motivation, and technology can be used to minimize declines ${ }^{(8)}$.

A training program design must adjust to the current times, including different modalities, such as using multimedia resources and e-learning. However, the population to whom they target limits their options, especially if their level of literacy is low or if their economic resources are scarce. It is clear that programs with face-to-face components impose themselves and add value to social interaction. We are faced with training processes that benefit from group strategies, since people share experiences, are motivated by successes and compete healthily.

Assessing the impact of a program aimed at the public is not always easy, however it is relevant to avoid acting based on improvisation or the lack of direction and planning. Assessment can be verified in two ways $s^{(5)}$ : formative and summative. The first reflects satisfaction and the fulfillment of expectations, which can be measured earlier. The second one verifies the differences before and after the program, specifically in the addition of physical exercise, in improving memory and better emotional management; changes in the eating plan; functional performance and social activities; in interpersonal and cultural involvement, among others, with a more accurate metric assessment available for this purpose. 
A true assessment of a program's implementation is perceived in the long term. Assessment models with longitudinal contours are more adequate, despite the difficulties in keeping populations stable throughout the study/program. Indirectly, it is possible to assess through the rates of morbidity, mortality, average life expectancy, healthy life expectancy or adjusted quality of life.

This study aims to carry out the first assessment of the program introduced, i.e., assessment of the formative type.

\section{OBJECTIVE}

To assess the results of a training program focused on the well-being of elderly individuals from the perspective of users, through their opinion on the program impact on their active aging.

\section{METHODS}

\section{Ethical aspects}

This study was approved by the Ethics Committee of Universidade de Évora. Procedures were carried out to guarantee ethical and legal principles, such as information on the program's objectives, the question leading to answers and the relevance of the study, for a free and informed decision of individuals to participate.

\section{Theoretical-methodological framework}

This is a qualitative research that followed the Consolidated Criteria for Reporting Qualitative Research (COREQ) guidelines and recommendations. The focus group technique was used to carry out this research. This technique is characterized by conducting a group interview in order to capitalize on communication between research participants and generate data in a given cultural context. Focus group explicitly uses group interaction as part of the method, in which people are encouraged to talk to each other by asking questions, exchanging ideas and commenting on each other's experiences and points of view. Planning and carrying out focus group followed the sampling and composition of the group, conducting focus group, analyzing and presenting data ${ }^{(9)}$.

The target group was initially composed of 30 individuals, 10 of whom were invited to participate in focus group. There was participation of a researcher who took over the role of facilitator, and who was not involved in the training program. She is a professor, doctoral student and with experience using the faceto-face method. The interviewer's ability to listen and interest in this type of investigation is important. There was a moment of personal presentation, referring to the objectives and reasons for the research, as the activity started. The research methodology was clarified and the inducing question was introduced:"what is the impact of the training program on your daily life?".

\section{Participants}

The target group was composed of 30 people, all elderly women older than 65 years, female, thus constituting a homogeneous group. The 10 invited people accepted to participate, without giving up.
The sample was intentional, consisting of elderly women aged 65 years and older, who lived independently in the community, used to work, retired and attended a Social Center in the city of Évora, Portugal.

\section{Context}

The data were collected in a Social Center in the city of Évora for people aged 65 and older. It is a leisure space that offers recreational, informative and training activities. Only the researcherinterviewer and the participating elderly people were present during focus group.

\section{Data collection}

To collect the data, the focus group technique was used and the answers were induced from the question: "what is the impact of the training program on your daily activities?". All statements were recorded on audio, after prior authorization from the informants, and field notes were taken. The interviews took 90 minutes.

\section{Data analysis}

The data collected were transcribed and submitted to lexical analysis by Alceste ${ }^{(10-11)}$.

The program took as a reference the text obtained from the transcripts of all interviews and assumed it as a corpus, entitled initial context unit (ICU). The software divided the corpus into Elementary Context Units (ECUs) and organized them into classes. The relationship that was defined between the classes was presented in a dendrogram (it will be explored later, according to Figure 3).

In the context of lexical analysis, the words in the corpus have been reduced from their root, for instance, "kn" representing the words know, known, and knew. Recognizing the lexical field of reduced forms (family of reduced words) is described in the dictionary created by the Alceste program. In the dictionary, co-occurrences of these reduced forms are identified and classes are created. Co-occurrences were classified according to their respective vocabularies and the set of them categorized, according to the frequency with which these reduced forms occur.

From this processing, matrices were created by crossing reduced shapes and ECUs. The classes were obtained from the chi-square test, which associates the reduced forms and ECUs. If there are different sizes of ECUs, descending hierarchical classification was applied. This type of analysis creates classes of ECUs that, at the same time, present vocabulary similar to each other and vocabulary different from the ECUs of other classes. The program provides a list of ECUs specific to each class; each one is accompanied by its order number in the corpus, their class number and the chi-square test.

\section{RESULTS}

The corpus resulted in a matrix consisting of three classes, which are associated with significant words, whose weight is verified by the chi-square test represented by $\mathrm{X} 2$ (Chart 1 ). 
Chart 1 - Words significantly associated with the analyzed word classes

\begin{tabular}{|c|c|c|c|c|c|c|c|c|}
\hline \multicolumn{3}{|c|}{ Class 1 (22 ECU-28\%) } & \multicolumn{3}{|c|}{ Class 2 (31 ECU-41\%) } & \multicolumn{3}{|c|}{ Class 3 (24 ECU-31\%) } \\
\hline Word & Frequency & $x^{2}$ & Word & Frequency & $x^{2}$ & Word & Frequency & $x^{2}$ \\
\hline Know & 12 & 10 & Day & 13 & 13 & Miss & 7 & 17 \\
\hline Want & 15 & 9 & Had & 7 & 11 & Life & 5 & 12 \\
\hline Say & 24 & 8 & Go & 5 & 8 & Head & 5 & 12 \\
\hline Have & 13 & 8 & Activity & 7 & 7 & Pull & 5 & 12 \\
\hline Walk & 7 & 7 & Interesting & 3 & 5 & Ask & 6 & 8 \\
\hline Can & 10 & 6 & Other & 6 & 5 & Influence & 3 & 7 \\
\hline
\end{tabular}

Note: ECU: Elementary Context Units.

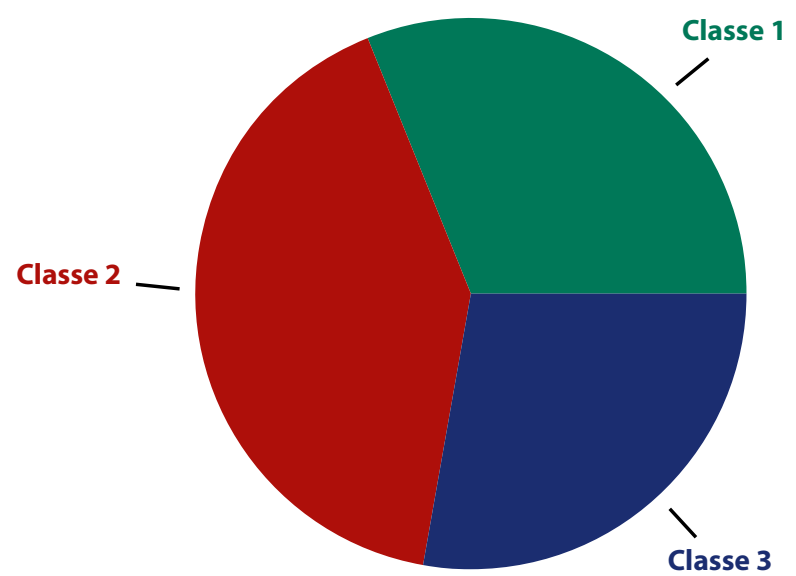

Classe 1 : 22 u.c.e soit $28.0 \%$

Classe 2 : 31 u.c.e soit $41.0 \%$

Classe 3 : 24 u.c.e soit $31.0 \%$

\section{Mots analysés}

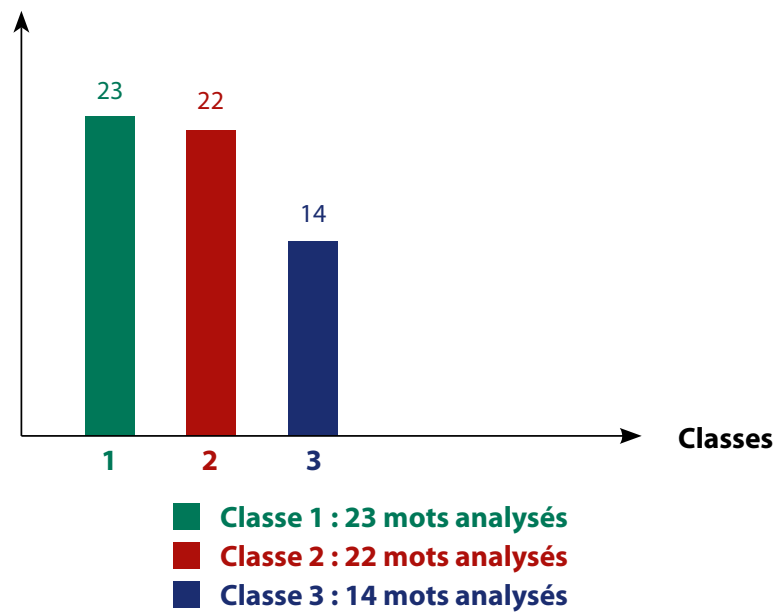

Figure 2 - Distribution of the Elementary Context Units in classes, the respective numbers of the words analyzed

The analyzed data revealed a wealth of vocabulary of $95.24 \%$, whose words were organized into $101 \mathrm{ECU}$. The ECUs correspond to $76 \%$ of the data obtained, thus representing an indicator of the number of words or lexicons available with capacity for analysis from corpus. The material was organized in 3 classes. Class 1 corresponded to $28 \%$ of the total and was composed of $22 \mathrm{ECU}$; class 2 corresponded to $41 \%$ of the total, with $31 \mathrm{ECU}$; and class 3 accounted for $31 \%$, consisting of 24 ECU. The 101 ECU obtained were organized in two descending hierarchical classifications that stabilized in the number of 3 classes.

To understand class content, it was necessary to locate the words in the ECUs associated with each one. Class I was associated with 23 words; class II, with 22; and class III, with 14 (Figure 2).

The names were assigned to the classes according to the content expressed in the respective context units. Thus, class 2 was called "Activity-Expectation", as the context units showed conversations that, in themselves, took on a positive meaning due to the opportunity to participate in activities. Diversity and regularity were enhancement for their frequency and the realization of a created expectation.

oh, I already realized it was me who misunderstood, yes, that is great the clarification is all right, all right now, except for Tuesday; there is nothing, there is nothing more, we sat here, we talked there with Ambrose, we talked with everyone who comes [...]. (ECU 79 and $\left.x^{2}=22\right)$

oh, what the ladies are saying to me is that on the other days there is nothing, there was also need for activities, exactly, because I already realized, everything goes away to the other side and here there is practically nobody, because they go where they really are there is [...]. (ECU 60 and $X^{2}=12$ )

I come here now because of this, me too, there has to be a change [...]. (ECU 92 and $\left.x^{2}=9\right)$

no, but here it is also important. Since there is not, people go where there is, they can have what they like to be busy. Exactly, if there were here, we have the gym on Monday. At least, everybody comes, if there was something here [...]. (ECU 62 and $\left.x^{2}=5\right)$

Class 1 was called "Health-Activity", since, in conversations, the word health was associated with the movement that is expressed on the floor, but in the sense of requesting conditions for action, such as knowledge, power and want. In this way, it seeks to express an interiorization and self-awareness.

I, then, I have high [pressure] tension, as I told you; and, in these sessions that you have been here for many years and this has contributed something to lower the tension [...]. (ECU 9 and $\left.X^{2}=16\right)$ 
again, and there are many [laughs], I can see that I do the same, because then, I could not eat potatoes, nor pasta, nor rice, nor bread, nor carrots. And then I say, then, I eat nothing, so I don't die from evil, I die from healing. I'm already seventy-seven years old, in no time I want to know [...]. (ECU 6 and $x^{2}=12$ )

everything on the same level, or some more than others; everything about the flu food, everything was said and everything and everything is fine and good, I also have something in my throat, I went for a biopsy. No, it's not a biopsy, it's an ultrasound, an ultrasound scan was something, and then he says no, there was nothing inflammation or I don't know what. Look, I have everything, everything is coming and the end [...]. ( $\left(\mathrm{ECU} 12\right.$ and $\left.x^{2}=9\right)$

but we distracted, I also don't know why they don't organize it, I don't know, there never was, I made fifteen knitted sweaters in my house and then I went to donate them to the church for the poor, but I mean [...]. (ECU 43 and $\left.x^{2}=8\right)$

Class 3 called "Mind-Body" is composed of entities that interact with each other, acting in a dynamic balance. It is expressed by a state of alertness to supply the changes (faults) that occur in the aging process, which reveals an attitude of curiosity and openness to learn.

and what happened here influenced your life in some way or nothing; really enjoyed. I liked it so much, that I'm going to all of them, I'm going to all of them. I haven't lost any yet. (ECU 20 and $\left.X^{2}=4\right)$

so, she used to do gymnastics here on the porch with us, played those games, here there is nothing. For example, we were all there in the room, she would put something here and then call one of us, and then say 'you now notice this', and then she would take one out and we had to see what and [what] was missing, I mean was to pull [...]. (ECU 38 and $x^{2}=5$ )

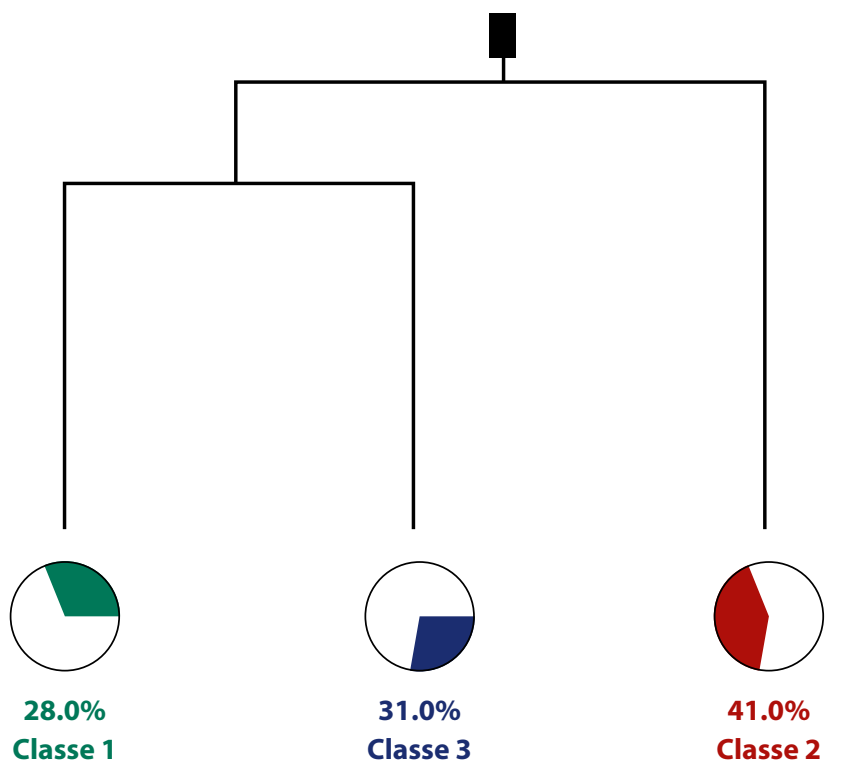

Figure 3 -Dendrogram with the relationships between the analyzed word classes

In addition, the relationships that were outlined between the word classes were verified, through the observation of the dendrogram performed from the analysis (Figure 3). The $101 \mathrm{ECU}$, which were analyzed, were divided into two branches. These remained linked as separate subsystems, however inseparable. Within the subsystems, closer conceptual associations can still be observed.

Looking at the dendrogram, it appears that one of the branches related to "activity - expectation" (class 2 ) has a higher percentage, since it is present in all classes, and, therefore, in the entire program. The other branch is subdivided into two other classes, which denounce the focuses of interest, which motivate the presence of participants in the program. The association between "health-activity" in class 1 shows the awareness of a reciprocal relationship between these two elements, in the same way it happens in the association between "mind-body". The position that class 3 occupies indicates that this unit is central to this structure.

\section{DISCUSSION}

In recent years, satisfaction with health and well-being and life has aroused interest in developed societies, and particularly in the academic dimension. The concept of aging in place ${ }^{(3)}$ is a reference for the definition of educational programs to be developed with elderly individuals. Conducting procedural assessments in educational programs developed in social environments ensures relevant guidelines for their continuity and to make them more suitable to the idiosyncrasies of the elderly population. It cannot be overlooked that well-being can be understood as a paradoxical phenomenon ${ }^{(12)}$, based on recent studies. Such research leads us to different results, depending on the pace of change, related to age and growing dependence, with health problems, loss of close relationships and approach of death ${ }^{(12)}$.

The difficulties in the transition process influence the perception of well-being. A literature review study ${ }^{(13)}$ found out about the need for studies with a qualitative nature, in order to obtain a more in-depth understanding of the lifestyle and quality of life of elderly individuals, as they are determinants in this assessment. Chen and colleagues conducted $\mathrm{a}^{(14)}$ study in Taiwan, China, with 83 residents of an institution, aged 65 to 100 years old. Analysis showed that physical activity alone does not have a direct impact on quality of life, but it does prove to be important in self-perceived health. In addition, participants who had more comorbidities attached greater importance to spirituality or religion.

A study ${ }^{(15)}$ developed in the state of Paraná, city of Maringá, Brazil, analyzed the contribution of living together in groups of elderly people. Fourteen elderly people participated in a qualitative study, whose interview data were submitted to content analysis. Three relevant categories were identified for active aging, namely: the social group as a learning space; the group as an element of health promotion and active aging; and the group as an opportunity for leisure and socialization for elderly individuals. Thus, their perception about the benefits of group living encompasses leisure, socialization, and learning, with benefits in physical and mental health and, ultimately, in quality of life.

A multicenter research ${ }^{(16)}$ carried out with 262 elderly people from Spain and 262 from Brazil, respectively, analyzed the participants' statements regarding their experiences in social groups. The sociability relations with friends stood out for the opportunity to share joys, sorrows, and knowledge. The results corroborate the studies referred to above, concluding that social relationships and social support positively favor the elderly's health. About 
subjective well-being and functionality, Sposito et al. ${ }^{(17)}$ conducted a study with 125 elderly people, predominantly women, born in the city of Campinas, São Paulo, Brazil. The authors concluded that elderly people had greater satisfaction with life and a better perception of their health, relating it to good physical performance, compared to other people.

In Tokyo(18), Japan, a study was developed that highlighted functional status as a prerequisite for quality of life in old age. Therefore, it can be concluded that the aforementioned studies are in agreement with the self-reported results by elderly individuals in a Social Center located in the region of Alentejo, Portugal.

\section{Study limitations}

The main limitations of this study are related to the methodology adopted, as qualitative research does not allow generalizations. The reality found here does not necessarily represent the reality of other Social Centers in the Alentejo region.

\section{Contributions to nursing, health, and public policies}

The results of this research contribute to studies and the performance of nursing professionals and other health professionals in designing more sensitive and effective strategies in the context of active, healthy, and aging in place. Moreover, it highlights important aspects for (re)structuring health policies and strategies for active aging, when working the mind and body dimensions and their relationship, to improve aging, as well as the perception of well-being and quality of life.

\section{CONCLUSION}

Implementing an educational program in a Community Center promoted the integration of an expectation that materializes in well-being, through activity and mind-body involvement. Physical activity does impact directly on the quality of life of elderly individuals, but on the self-perception of health and the negative way it is influenced. It is also possible to see that elderly people with more comorbidities attach greater importance to spirituality or religion. Considering the results, it is suggested that the project continuity should follow a line not only aiming at enhancing mental and physical functions, but also meeting the idiosyncrasies of the elderly population, to contribute to an active and healthy aging.

\section{ACKNOWLEDGMENT}

We would like to thank all elderly individuals of Évora for making this study possible.

\section{REFERENCES}

1. World Health Organization. World report on ageing and health [Internet]. Genève: World Health Organization; 2015 [cited 2019 Oct 20 ]. Available from: https://apps.who.int/iris/bitstream/handle/10665/186463/9789240694811_eng.pdf?sequence=1

2. Paúl C. Envelhecimento activo e redes de suporte social. Sociologia [Internet]. 2005[cited 2019 Oct 20];25:275-87. Available from: https://ojs. letras.up.pt/index.php/Sociologia/article/view/2392

3. lecovich E. Aging in place: from theory to practice. Anthropol Notebooks [Internet]. 2014[cited 2019 Oct 20];20(1):21-33. Available from: https://pdfs.semanticscholar.org/f9fc/8e6e859408543cb512a499d37a4267edb348.pdf

4. Fonseca A. Boas Práticas de Aging in Place. Divulgar para valorizar. Guia de Boas Práticas [Internet]. Lisboa: Fundação Calouste Gulbenkian. Faculdade de Educação e Psicologia — Universidade Católica Portuguesa; 2018[cited 2019 Oct 20]. Available from: https://repositorio.ucp. pt/bitstream/10400.14/25680/1/Boas\%20Pr\%C3\%A1ticas\%20de\%20Ageing\%20in\%20Place.pdf

5. Rowe JW, Kahn RL. Successful aging. Gerontol. 1997;37(4):433-40. doi: 10.1093/geront/37.4.433

6. World Health Organization. Active ageing: a policy framework [Internet]. Geneva: World Health Organization; 2002[cited 2019 Oct 20]. Available from: https://apps.who.int/iris/bitstream/handle/10665/67215/WHO_NMH_NPH_02.8.pdf

7. Pimentel L, Lopes SM, Faria S. Envelhecendo e aprendendo: a aprendizagem ao longo da vida no processo de envelhecimento ativo. Lisboa: Coisas de Ler Edições; 2016.

8. Caprara M, Molina MÁ, Schettini R, Santacreu M, Orosa T, Mendoza-Núñez VM, et al. Active aging promotion: results from the vital aging program. Curr Gerontol Geriatr Res. 2013;ID817813. doi: 10.1155/2013/817813

9. Kitzinger J. Qualitative research: introducing focus groups. BMJ [Internet]. 1995[cited 2019 Oct 20];311(7000):299-302. Available from: http://greenmedicine.ie/school/images/Library/Introducing\%20Focus\%20Groups.pdf

10. Reinert PM. Classification descendante hierarchique et analvse lexicale par contexte-application au corpus des poesies D'A. Rihbaud. Bull Sociol Methodol. 1987;13(1):53-90. doi: 10.1177/075910638701300107

11. Illia L, Sonpar K, Bauer MW. Applying co-occurrence text analysis with ALCESTE to studies of impression management. Br J Manag. 2014;25(2):352-72. doi: 10.1111/j.1467-8551.2012.00842.x

12. Léna P. Os limites do crescimento econômico e a busca pela sustentabilidade: uma introdução ao debate. In Léna P, Nascimento EP. (Orgs). Enfrentando os limites do crescimento: sustentabilidade, decrescimento e prosperidade [Internet]. Rio de Janeiro: IRD Éditions; 2018[cited 2019 Oct 20]:23-44. Available from: https://www.academia.edu/21918892/Enfrentando_os_limites_do_crescimento_sustentabilidade_decrescimento_e_prosperidade

13. Ferreira LK, Meireles JF, Ferreira ME. Evaluation of lifestyle and quality of life in the elderly: a literature review. Rev Bras Geriatr Gerontol. 2018 Oct;21(5):616-27. doi: 10.1590/1981-22562018021.180028 
14. Chen YH, Lin LC, Chuang LL, Chen ML. The relationship of physiopsychosocial factors and spiritual well-being in elderly residents: implications for evidence-based practice. Worldviews Evid Based Nurs. 2017;14(6):484-91. doi: 10.1111/wvn.12243

15. Previato GF, Nogueira IS, Mincoff RC, Jaques AE, Carreira L, Baldissera VD. Conviviality groups for elderly people in primary health care: contributions to active aging. Rev Pesqui: Cuid Fundam. 2019;11(1):173-80. doi: 10.9789/2175-5361.2019.v11i1.173-180

16. Wichmann FM, Couto AN, Areosa SV, Montañés MC. Companionship groups as support to improve the health of the elderly. Rev Bras Geriatr Gerontol. 2013;16(4):821-32. doi: 10.1590/S1809-98232013000400016

17. Sposito G, Diogo MJ, Cintra FA, Neri AL, Guariento ME, Sousa ML. Relationship between subjective well-being and the functionality of elderly outpatients. Rev Bras Fisioter. 2010;14(1):81-9. doi: 10.1590/S1413-35552010000100013

18. Asakawa T, Koyano W, Ando T, Shibata H. Effects of functional decline on quality of life among the Japanese elderly. Int J Aging Hum Dev. 2000;50(4):319-28. doi: 10.2190/3TR1-4V6R-MA5M-U1BV 